\title{
Effect of Plant Growth Regulators on Tree Growth and Yield of Pomegranate (Punica granatum L.) cv. Kandhari
}

\author{
Chahat Thakur* and C.L. Sharma \\ Department of Fruit Science, Dr. Y S Parmar University of Horticulture Forestry, \\ Nauni, Solan (H.P) 173230, India \\ *Corresponding author
}

\begin{abstract}
A B S T R A C T
Keywords

Pomegranate, PGRs, Growth, Yield

Article Info

Accepted:

04 August 2020

Available Online:

10 September 2020

Pomegranate (Punica granatum L.) belongs to the family Punicaceae and it is one of the favourite table fruits in the world, due to its refreshing juice with nutritional and medicinal properties. It is obvious that changes in the level of endogenous hormones due to biotic and abiotic stress alter the crop growth and any sort of manipulation including exogenous application of growth substances would help for yield improvement. So, an investigation was carried out in the Pomegranate Block of Model farm of Dr YS Parmar University of Horticulture and Forestry, Nauni, Solan (H.P), India during the year 2016 and 2017. The pomegranate trees $\mathrm{cv}$. Kandhari under investigation were subjected to foliar spray of plant growth regulators viz. NAA, $\mathrm{GA}_{3}, 6-\mathrm{BA}$, their combination and control at different concentrations. The study was conducted to determine the effect of plant growth regulators on tree growth and yield. On the basis of results obtained in the present investigation it is concluded that plant growth regulators and nutrients application revealed that NAA 30ppm (May) followed by $\mathrm{GA}_{3} 75 \mathrm{ppm}$ (June) and 6-BA (May) was proved to be most effective as it improved the growth and increased yield of pomegranate. While from economic point of view also NAA was superior to $\mathrm{GA}_{3}$ and 6-BA because of its higher net returns and lower cost when compared with other two growth regulators.
\end{abstract}

\section{Introduction}

Pomegranate (Punica granatum L.) is one of the oldest known edible fruits and is capable of growing in different agro-climatic conditions ranging from the tropical to subtropical (Levin, 2006; Jalikop, 2007). Pomegranate belongs to family Punicaceae and is native to Persia (Iran), Afganistan and Baluchistan (De Candole, 1967). It is one of the esteemed dessert fruit and is very much liked by people for its cool refreshing juice, taste and being highly valued for its nutritional and medicinal properties. Kandhari is a large fruited variety with deep red skin and sub-acidic taste (Singh, 2004). Trees are deciduous, vigorous and upright growing. It is regular bearer with good yield per tree. It bears only ambe bahar (April-May flowering). Despite this fact, pomegranate culture has always been restricted and generally considered as a minor crop. In Himachal Pradesh, pomegranate is mainly cultivated under rainfed conditions, therefore, 
its yield and quality is adversely affected during drought and rainfall conditions. Plant growth regulators are used to improve fruit size and quality, extend the storage life and to increase the profitability in some fruits (Lawes and Woolley, 2001). They have a key role in different physiological processes related to growth and development of crops. Plant growth regulators have been used for beneficial effects like fruit size, appearance and aril quality i.e. to improve physical characteristics and fruit quality of pomegranate (Anawal et al., 2016).

\section{Materials and Methods}

The present investigation on "Studies on effect of plant growth regulators on yield and quality of pomegranate (Punica granatum $\mathrm{L}$.) cv. Kandhari." was carried out in the Pomegranate Block of Model farm of Dr YS Parmar University of Horticulture and Forestry, Nauni, Solan (H.P), India during the year 2016 and 2017. For the present study, 45 trees were selected on the basis of uniform vigour and were maintained under uniform cultural practices during the entire course of investigation. The experiments were laid out on 7 year old pomegranate cv. Kandhari planted at a spacing of $4 \mathrm{~m} \times 2 \mathrm{~m}$ in the randomized block design having 15 treatments and each treatment replicated thrice. The pomegranate trees cv. Kandhari under investigation were subjected to foliar spray of plant growth regulators viz. NAA, $\mathrm{GA}_{3}$, 6-BA, their combination and control at different concentrations in mid may and June.

Technical programme of work

\begin{tabular}{|c|l|c|c|}
\hline Treatments & \multicolumn{1}{|c|}{ Chemicals } & Concentration & Time of application \\
\hline $\mathbf{T}_{\mathbf{1}}$ & Naphthalene acetic acid (NAA) & $20 \mathrm{ppm}$ & Mid May \\
\hline $\mathbf{T}_{\mathbf{2}}$ & Naphthalene acetic acid (NAA) & $30 \mathrm{ppm}$ & Mid May \\
\hline $\mathbf{T}_{\mathbf{3}}$ & Naphthalene acetic acid (NAA) & $20 \mathrm{ppm}$ & Mid June \\
\hline $\mathbf{T}_{\mathbf{4}}$ & Naphthalene acetic acid (NAA) & $30 \mathrm{ppm}$ & Mid June \\
\hline $\mathbf{T}_{\mathbf{5}}$ & Gibberellic acid $\left(\mathrm{GA}_{3}\right)$ & $50 \mathrm{ppm}$ & Mid May \\
\hline $\mathbf{T}_{\mathbf{6}}$ & Gibberellic acid $\left(\mathrm{GA}_{3}\right)$ & $75 \mathrm{ppm}$ & Mid May \\
\hline $\mathbf{T}_{\mathbf{7}}$ & Gibberellic acid $\left(\mathrm{GA}_{3}\right)$ & $50 \mathrm{ppm}$ & Mid June \\
\hline $\mathbf{T}_{\mathbf{8}}$ & Gibberellic acid $\left(\mathrm{GA}_{3}\right)$ & $75 \mathrm{ppm}$ & Mid June \\
\hline $\mathbf{T}_{\mathbf{9}}$ & Benzyl adenine $(6-\mathrm{BA})$ & $5 \mathrm{ppm}$ & Mid May \\
\hline $\mathbf{T}_{\mathbf{1 0}}$ & Benzyl adenine (6-BA) & $10 \mathrm{ppm}$ & Mid May \\
\hline $\mathbf{T}_{\mathbf{1 1}}$ & Benzyl adenine (6-BA) & $5 \mathrm{ppm}$ & Mid June \\
\hline $\mathbf{T}_{\mathbf{1 2}}$ & Benzyl adenine (6-BA) & $10 \mathrm{ppm}$ & Mid June \\
\hline $\mathbf{T}_{\mathbf{1 3}}$ & NAA+GA $+\mathrm{BA}$ & $20 \mathrm{ppm}+50 \mathrm{ppm}+5 \mathrm{ppm}$ & Mid May \\
\hline $\mathbf{T}_{\mathbf{1 4}}$ & NAA+GA $+\mathrm{GA}_{3}+\mathrm{BA}$ & $20 \mathrm{ppm}+50 \mathrm{ppm}+5 \mathrm{ppm}$ & Mid June \\
\hline $\mathbf{T}_{\mathbf{1}}$ & Control & $($ Water spray) & Mid May/ June \\
\hline
\end{tabular}

Before spraying, $0.5 \mathrm{ml}$ of wetting agent (Indtron-AE) per litre of solution was added as surfactant to reduce surface tension and to facilitate the absorption of solution was sprayed. Ten shoots from the current season's growth were randomly selected from all over the periphery of each tree for annual shoot growth and return bloom. For leaf area and chlorophyll content, fully developed and matured leaves from the current season's were randomly selected from all the four directions of the tree periphery and detached in the first week of July. The mean yield per tree in number of fruits and weight were also recorded. The data were statically analyses and interpreted. 


\section{Results and Discussion}

The data pertaining to the effect of plant growth regulators on growth, yield and return bloom are presented in Tables 1 to 3 .

\section{Annual shoot growth}

The perusal of data (Table 1) indicates that the application of NAA, $\mathrm{GA}_{3}, 6-\mathrm{BA}$ and their combination at different concentrations exerted the significant effect on annual shoot growth, which varied from 23.78 to $31.92 \mathrm{~cm}$.

The significantly maximum shoot growth $(31.92 \mathrm{~cm})$ was recorded with treatment $\mathrm{GA}_{3}$ $75 \mathrm{ppm}\left(\mathrm{T}_{8}\right)$, which was found to be statistically at par with the treatments NAA 20ppm $\quad\left(\mathrm{T}_{3}\right), \quad \mathrm{GA}_{3} \quad 50 \mathrm{ppm} \quad\left(\mathrm{T}_{7}\right)$, $\mathrm{NAA}+\mathrm{GA}_{3}+\mathrm{BA} \quad 20 \mathrm{ppm}+50 \mathrm{ppm}+5 \mathrm{ppm}\left(\mathrm{T}_{13}\right)$, NAA 20ppm $\left(\mathrm{T}_{1}\right)$ and control $\left(\mathrm{T}_{15}\right)$ producing annual shoot growth of $31.59 \mathrm{~cm}, 31.43 \mathrm{~cm}$, $31.09 \mathrm{~cm}, 29.80 \mathrm{~cm}$ and $28.99 \mathrm{~cm}$, respectively. However, the minimum shoot growth $(23.78 \mathrm{~cm})$ was registered in the treatment 6-BA 5ppm $\left(\mathrm{T}_{9}\right)$, when applied in the month of May.

\section{Canopy volume}

It is evident from data (Table 1) that application of NAA, $\mathrm{GA}_{3}, 6-\mathrm{BA}$ and their combination at different concentrations significantly affected the canopy volume, which varied from 2.44 to $3.44 \mathrm{~m}^{3}$.

The maximum canopy volume $\left(3.44 \mathrm{~m}^{3}\right)$ was also recorded with the treatment $\mathrm{GA}_{3} 75 \mathrm{ppm}$ $\left(\mathrm{T}_{8}\right)$, when applied in the month of June, closely followed and statistically at par with the treatments $\mathrm{GA}_{3} 75 \mathrm{ppm}\left(\mathrm{T}_{7}\right), \mathrm{GA}_{3} 50 \mathrm{ppm}$ $\left(\mathrm{T}_{5}\right), \mathrm{NAA}+\mathrm{GA}_{3}+\mathrm{BA} 20 \mathrm{ppm}+50 \mathrm{ppm}+5 \mathrm{ppm}$ $\left(\mathrm{T}_{14}\right)$ and NAA 20ppm $\left(\mathrm{T}_{1}\right)$ resulting in canopy volume of $3.43 \mathrm{~m}^{3}, 3.40 \mathrm{~m}^{3}, 3.12 \mathrm{~m}^{3}$ and $3.11 \mathrm{~m}^{3}$, respectively. The minimum canopy volume $\left(2.44 \mathrm{~m}^{3}\right)$ was recorded in the treatment 6-BA $10 \mathrm{ppm}\left(\mathrm{T}_{12}\right)$, which was found at par with control $\left(\mathrm{T}_{15}\right)$.

\section{Leaf area}

The perusal of data (Table 2) on the effect of plant growth regulators on leaf area in pomegranate clearly reveals that applications of NAA, $\mathrm{GA}_{3}, 6-\mathrm{BA}$ and their combination at different concentrations significantly influenced the leaf area, which ranged from 13.63 to $18.34 \mathrm{~cm}^{2}$.

The maximum leaf area $\left(18.34 \mathrm{~cm}^{2}\right)$ was recorded with the treatment 6-BA $10 \mathrm{ppm}$ $\left(\mathrm{T}_{10}\right)$, when applied in the month of May, which was statistically at par with treatments NAA 20ppm $\left(\mathrm{T}_{3}\right)$, 6-BA 10ppm $\left(\mathrm{T}_{12}\right)$, NAA 20ppm $\left(\mathrm{T}_{1}\right)$ and 6-BA 5ppm $\left(\mathrm{T}_{9}\right)$ having leaf area $16.82 \mathrm{~cm}^{2}, 16.51 \mathrm{~cm}^{2}, 16.50 \mathrm{~cm}^{2}$ and $16.47 \mathrm{~cm}^{2}$, respectively.

However, the minimum leaf area $\left(13.63 \mathrm{~cm}^{2}\right)$ was registered with the treatment $\mathrm{GA}_{3} 75 \mathrm{ppm}$ $\left(\mathrm{T}_{6}\right)$, when applied in the month of May.

\section{Chlorophyll content}

The data pertaining to the effect of plant growth regulators on chlorophyll content in pomegranate $\mathrm{cv}$. Kandhari are presented in Table 2. It is evident from data that applications of NAA, $\mathrm{GA}_{3}, 6-\mathrm{BA}$ and their combination at different concentrations exhibited non-significant effect on chlorophyll content.

However, the maximum chlorophyll content was recorded with treatment 6-BA 10ppm $\left(\mathrm{T}_{10}\right)$, when applied in the month of May and minimum chlorophyll content was registered in the treatment $\mathrm{GA}_{3} 50 \mathrm{ppm}\left(\mathrm{T}_{5}\right)$, when applied in the month of May. 
Table.1 Effect of plant growth regulators on annual shoot growth and canopy volume of pomegranate cv. Kandhari

\begin{tabular}{|c|c|c|c|c|}
\hline & Treatments & $\begin{array}{c}\text { Time of } \\
\text { application }\end{array}$ & $\begin{array}{l}\text { Annual shoot } \\
\text { growth }(\mathrm{cm})\end{array}$ & $\begin{array}{c}\text { Canopy } \\
\text { volume }\left(\mathbf{m}^{3}\right)\end{array}$ \\
\hline $\mathbf{T}_{1}$ & NAA(20ppm) & Mid May & 29.80 & 3.11 \\
\hline $\mathbf{T}_{2}$ & NAA(30ppm) & Mid May & 27.50 & 2.84 \\
\hline $\mathbf{T}_{\mathbf{3}}$ & NAA(20ppm) & Mid June & 31.59 & 2.51 \\
\hline $\mathbf{T}_{4}$ & NAA(30ppm) & Mid June & 24.46 & 2.54 \\
\hline $\mathbf{T}_{5}$ & $\mathrm{GA}_{3}(50 \mathrm{ppm})$ & Mid May & 29.16 & 3.40 \\
\hline$T_{6}$ & $\mathrm{GA}_{3}(75 \mathrm{ppm})$ & Mid May & 26.31 & 2.46 \\
\hline $\mathbf{T}_{7}$ & $\mathrm{GA}_{3}(50 \mathrm{ppm})$ & Mid June & 31.43 & 3.43 \\
\hline $\mathbf{T}_{8}$ & $\mathrm{GA}_{3}(75 \mathrm{ppm})$ & Mid June & 31.92 & 3.44 \\
\hline $\mathbf{T}_{9}$ & $6-\mathrm{BA}(5 \mathrm{ppm})$ & Mid May & 23.78 & 2.67 \\
\hline$T_{10}$ & 6-BA(10ppm) & Mid May & 28.61 & 2.84 \\
\hline $\mathbf{T}_{11}$ & 6-BA(5ppm) & Mid June & 25.60 & 2.85 \\
\hline $\mathbf{T}_{12}$ & $6-\mathrm{BA}(10 \mathrm{ppm})$ & Mid June & 24.70 & 2.44 \\
\hline $\mathbf{T}_{13}$ & $\mathrm{NAA}+\mathrm{GA}_{3}+\mathrm{BA}(20 \mathrm{ppm}+50 \mathrm{ppm}+5 \mathrm{ppm})$ & Mid May & 31.09 & 2.92 \\
\hline $\mathbf{T}_{14}$ & $\mathrm{NAA}+\mathrm{GA}_{3}+\mathrm{BA}(20 \mathrm{ppm}+50 \mathrm{ppm}+5 \mathrm{ppm})$ & Mid June & 24.58 & 3.12 \\
\hline $\mathbf{T}_{15}$ & Control & $\begin{array}{l}\text { Mid May/ } \\
\text { June }\end{array}$ & 28.99 & 2.49 \\
\hline $\mathrm{CD}_{0.05}$ & & & 3.13 & 0.42 \\
\hline
\end{tabular}

Table.2 Effect of plant growth regulators on leaf area and chlorophyll content of pomegranate cv. Kandhari

\begin{tabular}{|c|c|c|c|c|}
\hline \multicolumn{2}{|r|}{ Treatments } & \multirow{2}{*}{$\begin{array}{c}\text { Time of } \\
\text { application } \\
\text { Mid May }\end{array}$} & \multirow{2}{*}{$\begin{array}{c}\begin{array}{c}\text { Leaf area } \\
\left(\mathbf{c m}^{\mathbf{2}}\right)\end{array} \\
16.50\end{array}$} & \multirow{2}{*}{$\begin{array}{c}\text { Chlorophyll } \\
\text { content }\left(\mathbf{m g ~ g}^{-1}\right) \\
2.90\end{array}$} \\
\hline $\mathbf{T}_{1}$ & NAA(20ppm) & & & \\
\hline $\mathbf{T}_{2}$ & NAA(30ppm) & Mid May & 14.85 & 2.57 \\
\hline $\mathbf{T}_{\mathbf{3}}$ & NAA(20ppm) & Mid June & 16.82 & 2.61 \\
\hline $\mathbf{T}_{4}$ & NAA(30ppm) & Mid June & 15.43 & 2.91 \\
\hline $\mathbf{T}_{5}$ & $\mathrm{GA}_{3}(50 \mathrm{ppm})$ & Mid May & 14.71 & 1.95 \\
\hline $\mathbf{T}_{6}$ & $\mathrm{GA}_{3}(75 \mathrm{ppm})$ & Mid May & 13.63 & 2.66 \\
\hline $\mathbf{T}_{7}$ & $\mathrm{GA}_{3}(50 \mathrm{ppm})$ & Mid June & 14.34 & 2.32 \\
\hline $\mathbf{T}_{8}$ & $\mathrm{GA}_{3}(75 \mathrm{ppm})$ & Mid June & 14.58 & 2.72 \\
\hline $\mathbf{T}_{9}$ & 6-BA(5ppm) & Mid May & 16.47 & 3.14 \\
\hline $\mathbf{T}_{10}$ & 6-BA(10ppm) & Mid May & 18.34 & 3.34 \\
\hline $\mathbf{T}_{11}$ & 6-BA(5ppm) & Mid June & 15.84 & 3.02 \\
\hline $\mathbf{T}_{12}$ & $6-\mathrm{BA}(10 \mathrm{ppm})$ & Mid June & 16.51 & 2.75 \\
\hline $\mathbf{T}_{13}$ & $\mathrm{NAA}+\mathrm{GA}_{3}+\mathrm{BA}(20 \mathrm{ppm}+50 \mathrm{ppm}+5 \mathrm{ppm})$ & Mid May & 14.32 & 2.76 \\
\hline $\mathbf{T}_{14}$ & $\mathrm{NAA}+\mathrm{GA}_{3}+\mathrm{BA}(20 \mathrm{ppm}+50 \mathrm{ppm}+5 \mathrm{ppm})$ & Mid June & 15.46 & 2.98 \\
\hline $\mathbf{T}_{15}$ & Control & $\begin{array}{l}\text { Mid May/ } \\
\text { June }\end{array}$ & 15.50 & 2.61 \\
\hline $\mathrm{CD}_{0.05}$ & & & 1.95 & NS \\
\hline
\end{tabular}


Table.3 Effect of plant growth regulators on flowering and yield of pomegranate cv. Kandhari

\begin{tabular}{|c|c|c|c|c|}
\hline \multicolumn{2}{|c|}{ Treatments } & \multirow{2}{*}{$\begin{array}{c}\begin{array}{c}\text { Time of } \\
\text { application }\end{array} \\
\text { Mid May }\end{array}$} & \multirow{2}{*}{$\begin{array}{c}\begin{array}{c}\text { Fruit yield } \\
\text { (kg plant }^{-} \\
\mathbf{1}_{\text {) }}\end{array} \\
14.57\end{array}$} & \multirow{2}{*}{$\begin{array}{c}\begin{array}{c}\text { Return } \\
\text { bloom } \\
(\%)\end{array} \\
119.81 \\
(10.97)\end{array}$} \\
\hline $\mathbf{T}_{1}$ & NAA(20ppm) & & & \\
\hline $\mathbf{T}_{2}$ & $\operatorname{NAA}(30 \mathrm{ppm})$ & Mid May & 19.93 & $\begin{array}{l}118.89 \\
(10.94)\end{array}$ \\
\hline $\mathbf{T}_{3}$ & NAA(20ppm) & Mid June & 16.57 & $\begin{array}{l}122.61 \\
(11.11)\end{array}$ \\
\hline $\mathbf{T}_{4}$ & NAA(30ppm) & Mid June & 17.19 & $\begin{array}{l}120.67 \\
(11.03)\end{array}$ \\
\hline $\mathbf{T}_{5}$ & $\mathrm{GA}_{3}(50 \mathrm{ppm})$ & Mid May & 16.05 & $\begin{array}{l}112.53 \\
(10.63)\end{array}$ \\
\hline $\mathbf{T}_{6}$ & $\mathrm{GA}_{3}(75 \mathrm{ppm})$ & Mid May & 11.76 & $\begin{array}{l}122.34 \\
(11.10)\end{array}$ \\
\hline $\mathbf{T}_{7}$ & $\mathrm{GA}_{3}(50 \mathrm{ppm})$ & Mid June & 14.21 & $\begin{array}{l}120.62 \\
(11.04)\end{array}$ \\
\hline $\mathbf{T}_{8}$ & $\mathrm{GA}_{3}(75 \mathrm{ppm})$ & Mid June & 15.57 & $\begin{array}{l}132.02 \\
(11.53)\end{array}$ \\
\hline $\mathbf{T}_{9}$ & 6-BA(5ppm) & Mid May & 10.20 & $\begin{array}{l}120.24 \\
(11.00)\end{array}$ \\
\hline $\mathbf{T}_{10}$ & 6-BA(10ppm) & Mid May & 10.74 & $\begin{array}{l}118.24 \\
(10.91)\end{array}$ \\
\hline$T_{11}$ & 6-BA(5ppm) & Mid June & 15.57 & $\begin{array}{l}136.56 \\
(11.72)\end{array}$ \\
\hline$T_{12}$ & 6-BA(10ppm) & Mid June & 10.06 & $\begin{array}{l}128.80 \\
(11.39)\end{array}$ \\
\hline $\mathbf{T}_{13}$ & $\mathrm{NAA}+\mathrm{GA}_{3}+\mathrm{BA}(20 \mathrm{ppm}+50 \mathrm{ppm}+5 \mathrm{ppm})$ & Mid May & 12.70 & $\begin{array}{c}119.62 \\
(10.98)\end{array}$ \\
\hline $\mathbf{T}_{14}$ & $\mathrm{NAA}+\mathrm{GA}_{3}+\mathrm{BA}(20 \mathrm{ppm}+50 \mathrm{ppm}+5 \mathrm{ppm})$ & Mid June & 19.43 & $\begin{array}{l}124.02 \\
(11.17)\end{array}$ \\
\hline $\mathbf{T}_{15}$ & Control & $\begin{array}{l}\text { Mid May/ } \\
\text { June }\end{array}$ & 11.55 & $\begin{array}{l}111.57 \\
(10.79)\end{array}$ \\
\hline $\mathrm{CD}_{0.05}$ & & & 6.40 & 0.54 \\
\hline
\end{tabular}

*Figures in the parentheses are square root transformed value 
Table.4 Per hectare cost benefit ratio of pomegranate (value in $\square$ )

\begin{tabular}{|l|c|c|c|c|}
\hline Treatments & Total cost & Gross return & Net return & C: B ratio \\
\hline NAA (20ppm) & $3,00,534$ & $9,50,000$ & $6,49,466$ & $1: 2.16$ \\
\hline NAA (30ppm) & $3,00,701$ & $11,12,500$ & $8,11,799$ & $1: 2.69$ \\
\hline GA3 (50ppm) & $3,03,525$ & $9,25,000$ & $6,21,475$ & $1: 2.05$ \\
\hline GA3 (75ppm) & $3,05,163$ & $10,50,000$ & $7,44,837$ & $1: 2.44$ \\
\hline 6-BA (5ppm) & $3,02,075$ & $10,12,500$ & $7,10,425$ & $1: 2.35$ \\
\hline 6-BA (10ppm) & $3,03,900$ & $9,75,000$ & $6,71,100$ & $1: 2.20$ \\
\hline $\begin{array}{l}\text { NAA+GA3+BA } \\
\text { (20ppm+50ppm+5ppm) }\end{array}$ & $3,05,684$ & $10,12,500$ & $7,06,816$ & $1: 2.31$ \\
\hline Control & $3,00,200$ & $8,25,000$ & $5,24,800$ & $1: 1.74$ \\
\hline
\end{tabular}

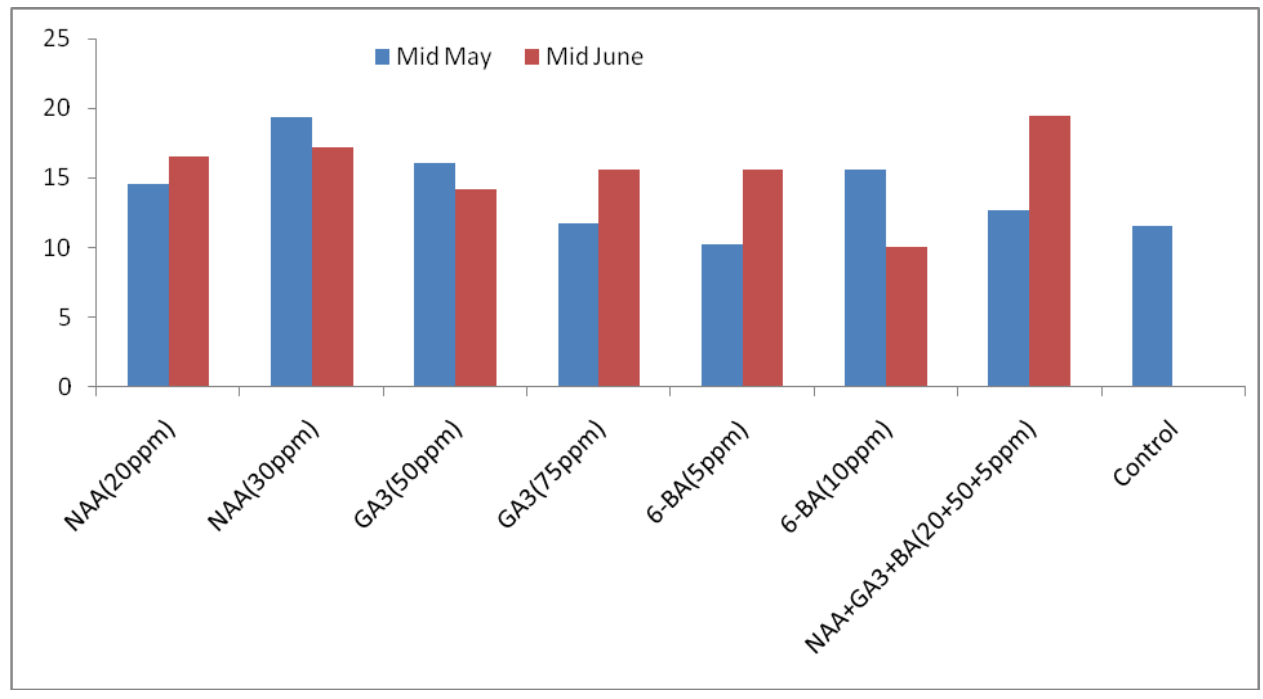

In the present studies the application of $\mathrm{GA}_{3}$ $75 \mathrm{ppm}$, when applied in the month of June resulted into maximum increase in shoot extension growth and canopy volume. The increase in vegetative growth with the application of $\mathrm{GA}_{3}$ may be attributed to the effect of $\mathrm{GA}_{3}$ on cell elongation (Mitchell et al., 1951). Xin et al., (1994) also found that foliar application of $\mathrm{GA}_{3}$ increased the shoot growth by promoting the protein synthesis and increasing transpirational area of apple trees. The effectiveness of $\mathrm{GA}_{3}$ might be due to its role in promoting growth and stimulated the rapid cell elongation in meristematic zone of vegetative plant organs. Due to cell elongation and division, the length and spread of branches might have increased, hence $\mathrm{GA}_{3}$ played an important role in enhancing the height and spread of the plant. Gibberellic acid promote the growth by increasing the plasticity of the cell wall followed by the hydrolysis of the starch into sugars, which reduces the cell water potential, resulting in the entry of water into the cell and causing elongation (Richard, 2006). The significant increase in vegetative growth with the application of $\mathrm{GA}_{3}$ has also been reported by Dalal et al., (2002), Jadhav et al., (2006) in Rangpur lime and by Singh (2008) and Digrase et al., (2016) in pomegranate. Maximum leaf area and chlorophyll content was recorded in the treatment 6-BA 10ppm. It might be due to the reason that cytokinins increased the cell division resulting into larger leaf area. Gardner et al., (1985) also reported that $\mathrm{GA}_{3}$ and $\mathrm{BA}$ promote the cell division in 
plant tissue. Cytokinins also brought down the rate of respiration and retarded the degradation of chlorophyll and enhances the rate of chlorophyll synthesis. Gintare et al., (2008) observed that benzyladenine increased leaf chlorophyll content by a strong retardation of the leaf senescence by retarding the terminal changes in chlorophyll or by preserving much of the chlorophyll.

\section{Fruit yield}

The data presented in Table 3 and Figure 3 indicate that the applications of NAA, $\mathrm{GA}_{3}, 6$ $\mathrm{BA}$ and their combination at different concentrations induced significant effect on fruit yield, which varied from 10.06 to 19.93 $\mathrm{kg}$ plant $^{-1}$. The significantly higher fruit yield $\left(19.93 \mathrm{~kg} \mathrm{plant}^{-1}\right)$ was recorded with treatment NAA 30ppm $\left(\mathrm{T}_{2}\right)$, when applied in the month of May, closely followed by NAA+GA + BA $(20 \mathrm{ppm}+50 \mathrm{ppm}+5 \mathrm{ppm}) \quad\left(\mathrm{T}_{14}\right)$ which yielded $19.43 \mathrm{~kg} \mathrm{plant}^{-1}$ as compared to control (11.55 kg plant $\left.^{-1}\right)$. However, treatments $\mathrm{T}_{1}, \mathrm{~T}_{3}, \mathrm{~T}_{4}$, $\mathrm{T}_{5}, \mathrm{~T}_{7}, \mathrm{~T}_{8}$ and $\mathrm{T}_{11}$ were also found to be statistically at par with the treatments NAA $30 \mathrm{ppm}\left(\mathrm{T}_{2}\right)$ and $\mathrm{NAA}+\mathrm{GA}_{3}+\mathrm{BA}$ (20ppm+ $50 \mathrm{ppm}+5 \mathrm{ppm})\left(\mathrm{T}_{14}\right)$. The minimum fruit yield $\left(10.06 \mathrm{~kg} \mathrm{plant}^{-1}\right)$ was registered in the treatment 6-BA 10ppm $\left(\mathrm{T}_{12}\right)$, when applied in the month of June.

\section{Return bloom}

The data regarding the effect of plant growth regulators on return bloom in pomegranate $\mathrm{cv}$. Kandhari presented in Table 3. It is pertinent from the data that application of NAA, GA 3 , 6-BA and their combination at different concentrations had significant effect on return bloom, varying between 136.56 per cent and 111.57 per cent.

The significantly higher return bloom $(136.56 \%)$ was recorded with treatment 6-BA $5 \mathrm{ppm}\left(\mathrm{T}_{11}\right)$ applied in the month of June, over the control treatment $\left(\mathrm{T}_{15}\right)$ accounting for
111.57 per cent. However, treatments $\mathrm{GA}_{3}$ $5 \mathrm{ppm}\left(\mathrm{T}_{8}\right)$ and 6-BA 10ppm $\left(\mathrm{T}_{12}\right)$ were found to be at par with 6-BA 5ppm $\left(\mathrm{T}_{11}\right)$ contributing to 132.02 and 128.80 per cent return bloom. The minimum return bloom $(111.57 \%)$ was registered in the treatment Control $\left(\mathrm{T}_{15}\right)$.

In the present study, the maximum yield was observed in the plants treated with the application of NAA 30ppm. This may be due to the better physiology of developing fruits in terms of better supply of water, nutrients and other compounds vital for their proper growth and development, which resulted in improved size and ultimately greater yield as compared to other treatments.

Beneficial effects of NAA were recorded by Ghosh et al., (2009) in cv. Ruby, Adi and Prasad (2012) in cv. Ganesh, Goswami et al., (2013) in cv. Sindhuri and Anawal et al., (2015) in cv. Bhagwa of pomegranate. In our studies 6-BA resulted the higher return bloom. It may be due to the fact that cytokinins conserved the higher amounts of carbohydrates and other metabolites in comparison to other treatments, which promoted the flowering in the following year. Mclaughlin and Greene (1984) had also observed that return bloom was increased by BA application in some apple cultivars.

\section{Economics}

\section{Gross return}

The data on gross return under different treatments in this experiment were given in Table 4. From the results, it was seen that NAA 30ppm gave highest gross return per hectare (Rs. 11,12,500) followed by $\mathrm{GA}_{3}$ $75 \mathrm{ppm}$ (Rs. 10,50,000) and the lowest with control (Rs. 8,25,000). 6-BA gave good returns but recorded lower net returns than the other two growth regulators due to its higher cost. 


\section{Net return}

The data on net return under different treatments in this experiment were given in Table 4. The data reveals that NAA 30ppm gave highest net return per hectare $(\square 8,11$, 799) followed by $\mathrm{GA}_{3} 75 \mathrm{ppm}(\square 7,44,837)$ and the lowest with Control ( $\square 5,24,800)$.

\section{Cost: benefit ratio}

The data on benefit cost ratio of different treatments was presented in Table 4. From the results, it was seen that NAA 30ppm recorded highest benefit cost ratio (2.69) followed by $\mathrm{GA}_{3}$ 75ppm (2.44) and the lowest with control (1.74). NAA recorded higher cost benefit ratio due to its higher net returns and lower cost than the other two growth regulator. 6-BA gave good returns but recorded lesser cost benefit ratio than the other two growth regulators due to its higher cost.

In conclusions on the basis of the results obtained during the present investigation, it is concluded that among various plant growth regulators, NAA 30ppm (May) followed by $\mathrm{GA}_{3}$ 75ppm (June) and 6-BA (May) was proved to be most effective as it improved the growth and increased yield of pomegranate. Also from the economic point of view, NAA was superior to $\mathrm{GA}_{3}$ and 6-BA because of its higher net returns and lower cost when compared with other two growth regulators.

\section{References}

Adi PR and Prasad DM. 2012. Effect of plant growth regulators on fruit characters and yield of pomegranate (Punica granatum L.) cv. Ganesh. International Journal of Plant Animal and Environmental Sciences 2: 91-93.

Anawal VV, Narayanaswamy $\mathrm{P}$ and Kumar YHS. 2015. Effects of plant regulators on induction of flowering in pomegranate (Punica granatum L.) $\mathrm{cv}$. Bhagwa. International Journal of Scientific Research 4:7-9.

Anawal VV, Narayanaswamy P and Ekabote SD. 2016. Effects of plant regulators on fruit-set and yield of pomegranate cv. Bhagwa. International Journal of Current Research 8:2908-2910.

Dalal SR, Patil SR, Gonge VS and Athawale RR. 2002. Effect of $\mathrm{GA}_{3}$ and urea on growth of Rangpur lime seedlings in nursery. Indian Journal of Citriculture 1:121-124.

De-Candole A. 1967. Origin of cultivated plants. Hafner Publishing Company New York. 441p.

Digrase SS, Tambe TB, Kadam AS and Kalalbandi BM. 2016. Effect of different plant growth regulators and chemicals on growth and yield of pomegranate (Punica granatum L.) cv. Bhagwa. Advance Research Journal of Crop Improvement 7:96-99.

Gardner FP, Pearce RB and Mitchell RL. 1985. Physiology of Crop Plants. Iowa State University Press, Ames, Iowa. pp.156-186.

Ghosh SN, Bera B, Ray S and Kundu A. 2009. Effect of plant growth regulators in yield and quality in pomegranate $\mathrm{cv}$. Rubi. Journal of Horticultural Sciences 4:158-160.

Gintare S, Uselis N, Kvikliene N, Samuoliene G, Sasnauskas A, Duchovskis. 2008. Effect of growth regulators on apple tree cv. Jonagold King photosynthesis and yield parameters. Scientific Articles 27: 23-32.

Goswami JD, Patel NM, Bhadauria HS and Wankhade VR. 2013. To study the effect of plant growth regulators on quality traits of pomegranate $\mathrm{cv}$. Sindhuri. The Asian Journal of Horticulture 8: 361-363.

Jadhav SB, Dhutraj DN and Bastewed TB. 
2006. Effect of growth regulators and urea sprays on growth of Rangpur lime seedling. Journal of Maharashtra Agriculture Universities 31:82-84.

Jalikop SH. 2007. Linked dominant alleles of inter-locus interaction results in a major shift in pomegranate fruit acidity of 'Ganesh' and 'Kabul Yellow’. Euphytica 158:201-207.

Lawes GS and Woolley DJ. 2001. The commercial use of plant growth regulators to regulate fruit development. Acta Horticulturae 553:149-150.

Levin GM (ed). 2006. Pomegranate. $1^{\text {st }}$ Edn. Third Millennium Publishing, East Libra Drive Tempe, AZ. pp.13-120.

Mclaughlin JM and Greene DW. 1984. Effect of benzyl adenine and daminozide on flowering of 'Early McIntosh'. In: Proceeding of the 11th Annual Meeting of the Plant Growth Regulation Society of America 78p.

Mitchell JW, Skages OP and Anderson. 1951. Plant growth stimulating hormones in immature bean seeds. Science 114:159-161.

Richard M. 2006. How to grow big peaches. Department of Horticulture, Virginia Tech. Blacksburg, VA 24061. www. Rce.rutgers.edu.

Singh DB. 2004. Screening of pomegranate (Punica granatum L.) cultivars for arid ecosystem. Indian Journal of Horticultural Sciences 74:604-606.

Singh G. 2008. Effect of irrigation, foliar fertilization and plant bioregulators on growth, yield and quality of pomegranate cv. G-137. PhD. Thesis. Dr YS Parmar University of Horticulture and Forestry, Nauni, Solan, HP, India.

Xin PG, Xiang SX, Che PG, Xin X and Chen KL. 1994. A study on distribution of PP333 in young trees and its growth inhibition effect and inhibition relieving with $\mathrm{GA}_{3}$. Journal of Shandong Agricultural University 25:1-8.

\section{How to cite this article:}

Chahat Thakur and Sharma, C.L. 2020. Effect of Plant Growth Regulators on Tree Growth and Yield of Pomegranate (Punica granatum L.) cv. Kandhari Int.J.Curr.Microbiol.App.Sci. 9(09): 336-344. doi: https://doi.org/10.20546/ijcmas.2020.909.043 